\title{
ISSN 2580 - 5339
}

\section{JURNAL ANALISIS SISTEM PENDIDIKAN TING G I}

\author{
VOLUME 1 NOMOR 1, JULI 2017
}

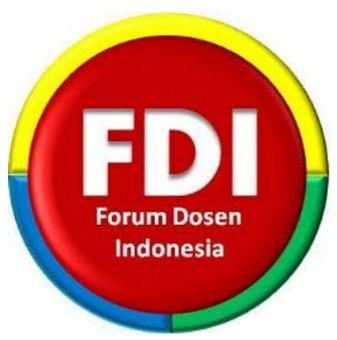

FORUM DOSEN INDONESIA

\begin{tabular}{|c|c|c|c|c|}
\hline $\begin{array}{c}\text { Jurnal } \\
\text { A nalisis }\end{array}$ & Vol. 1 & HIm. & JUL I 2017 & ISSN 2580 - 5339 \\
$\begin{array}{c}\text { Sistem } \\
\text { Pendidikan } \\
\text { Tinggi }\end{array}$ & No. 1 & $1-52$ & J & \\
\hline
\end{tabular}





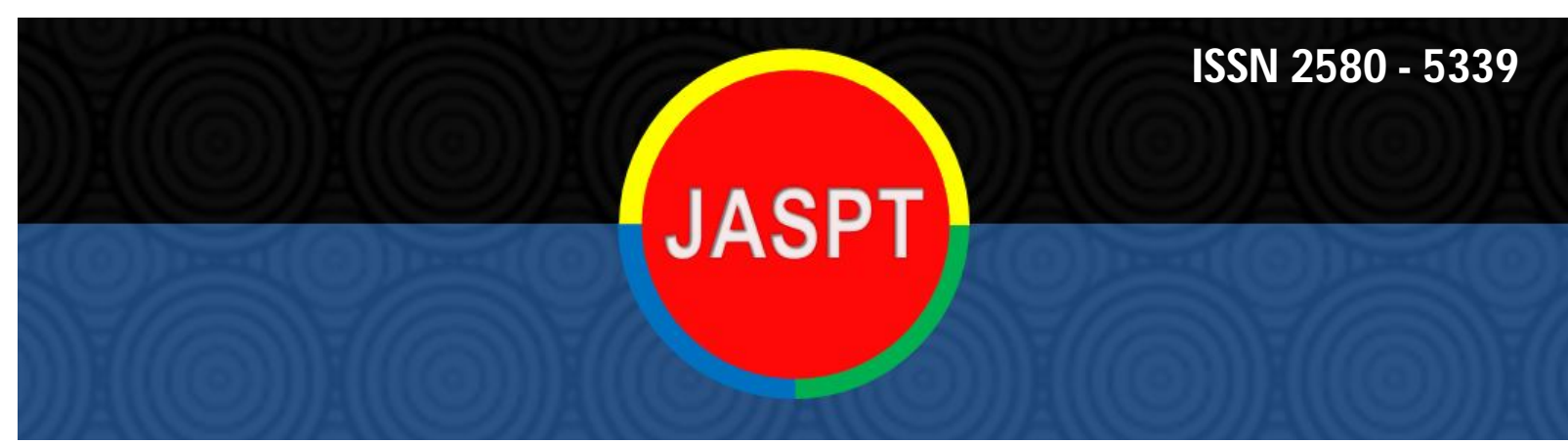

\section{JURNAL ANALISIS SISTEM PENDIDIKAN TINGG I}

\section{VOLUME 1 NOMOR 1, JULI 2017}

\section{EDITORIAL}

Dunia Pendidikan Tinggi telah berkembang sedemikian dinamis. Dinamika tersebut telah mewarnai kebijakan, proses pembelajaran, tenaga pendidik, tenaga kependidikan serta peserta didik termasuk sarana dan prasarana kegiatan PBM. Hal tersebut membuat tema tentang sistem pendidikan tinggi menjadi kajian yang menarik untuk dibahas.

Tulisan M ashadi dan Risky Irawan membahas tentang M odel Intensi M ahasiswa untuk berkarir di Bidang Perbankan Syariah. Tulisan tersebut membangun model tentang faktor-faktor yang mempengaruhi minat mahasiswa untuk berkarir di bidang Perbankan Syariah.

Sementara Gatut Rubino dan Nurida Finahari mengupas tentang Profesi Dosen dengan kesederhanaannya di tengah tugas dan tanggungjawab yang rumit. Tarida $M$ arlin Surya Manurung mengkaji keterkaitan M otivasi dan Perilaku Belajar dengan Prestasi Akademik mahasiswa yang digambarkan dengan capaian Indeks Prestasi K umulatif.

Sedangkan, Dian Cahya mengupas tuntas tentang esensi membangun kurikulum program studi Desain Komunikasi Visual dengan pendekatan Kompetensi Bisnis Inti. Di tulisan kelima, Faktor-faktor yang membentuk karakter mahasiswa diulas oleh $\mathrm{M}$ onica $\mathrm{M}$ ayeni manurung dan Rahmadi.

Terakhir, Rinda Cahyana dan Irmawati Sagala mengurai Model Sistem Perubahan Dalam Lingkup Sarjana. 


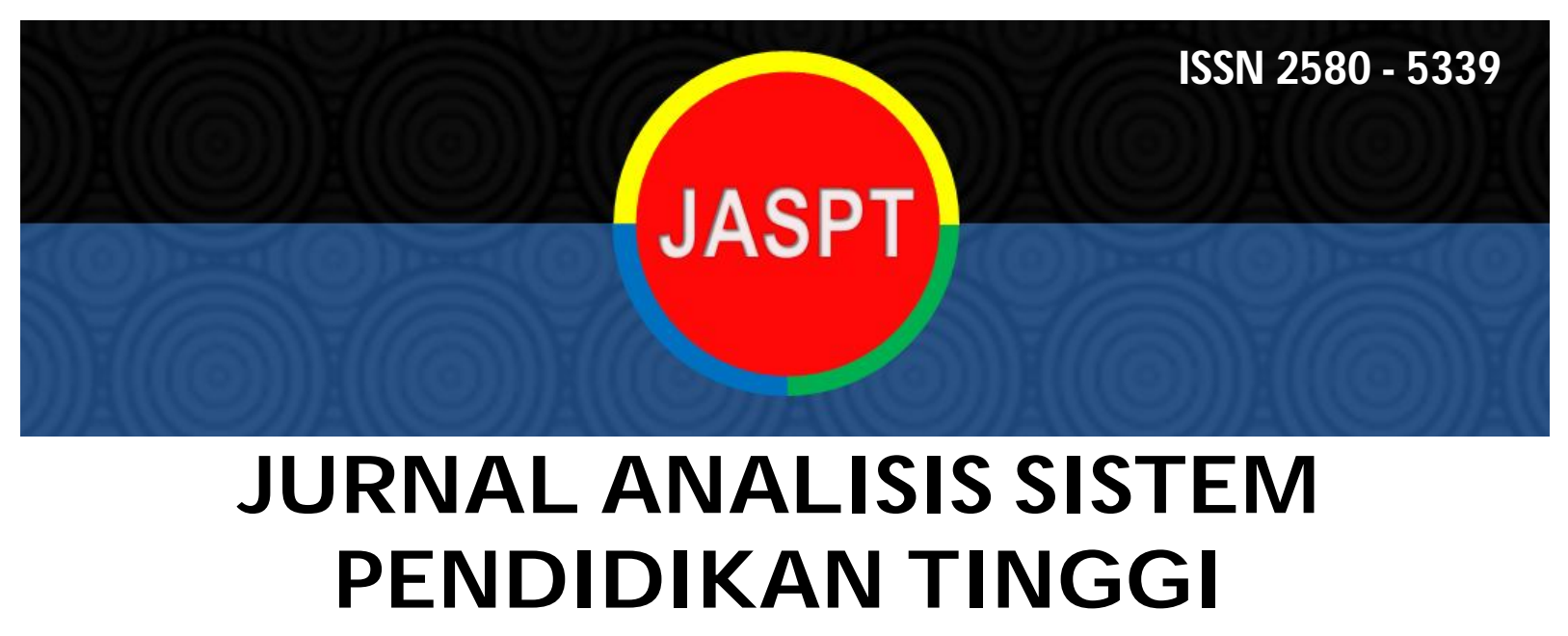

VOLUME 1 NOMOR 1, JULI 2017

\section{DAFTAR ISI}

Model Struktural $\mathrm{M}$ inat Mahasiswa Berkarir di Bidang PerbankanSyariah Sebagai Dasar Pengembangan Proses Pembelajaran ............................ $1-10$

DOSEN : Profil-profil Sederhana Dalam Profesi Y ang Rumit ................... $11-16$

Pengaruh Motivasi dan Perilaku Belajar Terhadap Prestasi Akademik Mahasiswa .... $\quad 17-26$

Membangun Infrastruktur Kurikulum Prodi DKV Berbasis Core Busines Competencies..................................... $27-40$

Identifikasi Faktor-faktor Pembentukan Karakter Mahasiswa........................ $41-46$

Model Sistem Perubahan Dalam Lingkup Program Sarjana ...................... 47 - 52 